\title{
Çalışma Sermayesi Etkinliği Ölçümünde Endeks Yöntemi: Borsa İstanbul Yiyecek-İçecek, Konaklama ve Havayolu Ulaştırma İşletmelerinde Bir Uygulama
} (Araştırma Makalesi)

Index Method in Working Capital Efficiency Measurement: An Application in Borsa Istanbul Food and Beverage, Lodging and Airline Transportation Companies

Doi: 10.29023/alanyaakademik.883758

\section{Fatih GÜNAY}

Dr. Ö̈rr. Üyesi, A ̈̆rr İbrahim Çeçen Üniversitesi, Turizm İşletmeciliği ve Otelcilik

Yüksekokulu

fgunay@agri.edu.tr

Orcid No: 0000-0003-0892-514X

Bu makaleye atıfta bulunmak için: Günay, F. (2021). "Çalışma Sermayesi Etkinliği Ölçümünde Endeks Yöntemi: Borsa İstanbul Yiyecek-İçecek, Konaklama ve Havayolu Ulaştırma İşletmelerinde Bir Uygulama”, Alanya Akademik Baklş, 5(3), Sayfa No.1411-1431.

\section{Anahtar kelimeler: \\ Çalışma Sermayesi Yönetimi, Endeks Yöntemi, Etkinlik, Turizm.}

Makale Geliş Tarihi: 20.02.2021 Kabul Tarihi: 07.09.2021

\begin{abstract}
ÖZET
Çalışma sermayesi kararları işletmelerin likidite, kredibilite ve satışların arttırllmasında etkilidir. Çalışma sermayesi yönetim etkinliği kârlılı̆̆ v ve firma değerini arttırabildiği gibi işletme başarısızlığına ve iflasa sebep olabilir. Endeks yöntemi satışlardaki değişimlerle yönetici kararlarının sonucu olan çalışma sermayesindeki değişimlerin ilişkilendirildiği etkinlik ölçüm yöntemidir. Finansman kararların dikkate almaması endeks yönteminin zaylf yönü olmakla birlikte diğer yöntemlere klyasla belirli üstünlükleri bulunmaktadır. Bu çalışmada endeks yöntemi açılklanarak, Borsa İstanbul'da işlem gören yiyecek içecek, konaklama ve havayolu ulaştırma işletmelerinde çalışma sermayesi yönetim etkinliğinin ölçülmesi amaçlanmıştır. Borsa İstanbul yiyecek içecek ve konaklama sektöründe listelenen 9 işletme ve havayolu ulaştırma sektöründen 2 işletmenin 20092019 dönemi yıllık gözlemlerinde etkinlik değerleri hesaplanmıştır. Endeks yöntemiyle gerçekleştirilen sınırlı literatüre katkı sağlayan çalışmada elde edilen bulgular, yiyecek içecek ve konaklama işletmeleri etkinliğinin dalgall, havayolu işletmeleri etkinliklerinin ise dengeli olduğunu göstermektedir. Ayrica yiyecek içecek ve konaklama işletmelerinde çalışma sermayesi yönetim etkinliğinin havayolu ulaştırma işletmelerine klyasla daha zaylf diğer ifadeyle satış gelirlerini arttırmada dönen varlık kullanım etkinliğinin yetersiz olduğu tespit edilmiştir. Turizmi ve sektörü etkileyen gelişmelerin olduğu dönemlerde satışlardaki daralmaya karşı yiyecek içecek ve konaklama işletmelerinin çalışma sermayesi kararlarında ayn yön ve düzeyde tepkiler vermediği sonucuna ulaşılmıştır.
\end{abstract}

\section{ABSTRACT}

Working capital decisions are effective in liquidity, credibility and increase in sales of companies. Efficient working capital management can increase 
Keywords:

Working Capital

Management, Index

Method, Efficiency,

Tourism. profitability and firm value. On the other hand, failure and bankruptcy can be the result of inefficiency in working capital management. The index method is one of the efficiency measurement methods that associate changes in sales with changes in working capital which is the result of managerial decisions. The index method, which has deficiencies such as not taking into consideration financing decisions, has some advantages over other methods. In this study, it is aimed to measure the working capital management efficiency in the restaurants and hotels, and airline transportation companies listed in Borsa Istanbul with the index method. Indices have been calculated in the annual observations of 9 companies listed in the Borsa Istanbul restaurants and hotels and 2 companies from the airline transportation sector for the 2009-2019 period. The findings of the study, which contributes to the limited literature on the index method, show that the efficiency of restaurants and hotels businesses is fluctuating and that of airline companies is balanced. In addition, it has been determined that working capital management efficiency in restaurants and hotels is weaker compared to airline companies, and current asset utilization efficiency is insufficient in increasing sales revenues. It has been determined that restaurants and hotels do not react in the same direction and level in their working capital decisions against the shrinkage in sales in times of developments affecting tourism and the sector.

\section{GİRIŞ}

Ekonomik faaliyetleri etkileyen gelişmeler ve yönetsel kararlar işletme performans ve başarısında belirleyici unsurlardır. Tarım ve sanayi sektörlerinde olduğu gibi hizmetler sektöründe faaliyet gösteren işletmeler de çeşitli risklerle karşı karşıyadır. Salgın, deprem, yangın, terör saldırıları, savaş, politik istikrarsızlık, finansal krizler gibi birçok faktör hizmet sektörlerinden turizm alanında faaliyet gösteren işletmeler için risk unsurudur (Shaw, Saayman ve Saayman, 2012). İşletmelerin riskten etkilenme derecesi ise riskin kaynağına, düzeyine, işletme faaliyet alanına ve yönetim performansına göre değişmektedir. Risklerin gerçekleşmesi, faaliyetlerin yavaşlamasına ve geçici olarak durdurulmasına neden olarak işletme gelirlerinde azalmayla sonuçlanacaktır.

İşletmelerde finans fonksiyonunun yerine getirilmesinde finans yöneticisi genel itibariyle yatırım, yatırımların finansmanı, kısa vadeli ödemeler ve eldeki fazla nakdin değerlendirmesi kararlarından sorumludur (Ceylan ve Korkmaz, 2018). İşletme fonksiyonlarının yerine getirilmesi her bir çalışanın katkılarına ve yönetici kararlarına bağlıdır. İşletme amaçlarının gerçekleştirilmesi için hedeflerin belirlenmesi ve bu hedeflere ulaşılmasında temel faktörlerin başında yönetsel kararlar gelmektedir.

Bir faaliyet döneminde nakde dönüşmesi beklenen işletme varlıkları çalışma sermayesini oluşturur. Gelirlerin artırılması ve işletme başarısı çalışma sermayesi yönetiminden etkilenir. Çalışma sermayesi yönetimi (ÇSY), dönen varlık yatırım kararları ve bu varlıkların finansman kararlarını kapsamaktadır (Moyer, McGuigan ve Kretlow, 2009: 550). İşletmenin gereğinden fazla nakit tutması, nakit benzeri varlıklara aşırı yatırım, hatalı kredili satış politikası ve aşırı stok bulundurulması atıl kaynaklara ve finansman maliyetlerinin artmasına, yetersiz yatırım ise satışların artırılamaması gibi çeşitli problemlere neden olmaktadır (Aksoy ve Yalçıner, 2008). Dönen varlıklara aşırı veya yetersiz yatırımın işletmelerde ek maliyetlere ve satışlarda istenen 
düzeye ulaşılamamasına neden olarak işletme kârını dolayısıyla kârlılığı ve firma değerini olumsuz etkilemektedir.

Riske duyarlılığın yüksek olduğu turizm sektöründe de çalışma sermayesi yönetimi ve çalışma sermayesi yönetiminde etkinliğin sağlanması işletmeler için hayati öneme sahiptir. Diğer ifadeyle işletme başarısında belirleyici unsurlardan biri çalışma sermayesi yatırım ve finansman kararları ile alınan kararlarla işletmelerde varlık kullanımında etkinliğin sağlanmasıdır (Saldanl1, 2012: 175; Ata ve Buğan, 2016: 30). Turizm sektörü işletmelerinde çalışma sermayesi yönetiminin bir sonucu olarak işletme likiditesi ile kârlılık arasında yüksek düzeyli bir ilişki bulunur (Hiadlovský, Rybovičová ve Vinczeová, 2016). Turizmin doğası gereği sektör işletmelerinin faaliyetleri dalgalı bir seyir izlemektedir. Satışlardaki azalma işletme likiditesinde bozulmalara sebep olacaktır. Çeşitli nedenlerle satışlarda yaşanan dalgalanma işletmelerin çalışma sermayesi ihtiyaçlarını farklılaştırmakta, bu dalgalanmalar karşısında çalışma sermayesi yönetiminde etkinlik yönetim kararlarıyla sağlanabilmektedir (Erdinç, 2008).

Konaklama, yiyecek içecek, havayolu ulaştırma işletmelerinde işletme karlılı̆̆ının belirleyicilerinin başında stoklanamaz kapasitenin kullanımı gelmektedir. İşletmenin tam kapasite faaliyet gösterebilmesi ve kapasite kullanım etkinliği, işletmenin kısa vadeli kararlarında diğer ifadeyle çalışma sermayesi yönetimi etkinliğine bağlıdır (Bridge ve Moutinho, 2000: 204). Turizm sektörü işletmelerinde vadesi gelen kredi yükümlülüklerinin karşılanamaması ve tedarikçilere ödemelerin zamanında yapılamaması, kredi sağlayanlar ve tedarikçilerle ilişkilerin bozulmasına ve işletmenin ilave maliyetlere katlanmasına neden olacaktır. Çalışan ücretlerinin ödenememesi emek yoğun sektör olan turizm işletmelerinde hizmet kalitesini düşürecektir. İşletme faaliyetlerinde aksamaların yanı sıra işletmenin kredili satışlar için yeterli kaynağa sahip olmaması işletme satış düzeyini etkiler. Bu durumların yaşanması ise işletmede entelektüel sermaye kaybına, sahipliğin el değiştirmesine veya iflas nedeniyle gerçek değerinin altında tasfiyesiyle sonuçlanabilecektir.

Sonuç olarak işletme faaliyetlerinin aksamadan sürdürülmesi, yükümlülüklerin yerine getirilmesi, satışların arttırılması, sermaye yatırımlarının verimliliği çalışma sermayesi yönetimi etkinliğine bağlıdır. Bu kapsamda bu çalışmada, çalışma sermayesi yönetim etkinliğinin ölçümünde alternatif bir yöntem olan ve Bhattacharya (1997) tarafindan geliştirilen endeks yönteminin açıklanması ve payları Borsa İstanbul'da işlem gören yiyecek içecek, konaklama ve havayolu ulaştırma işletmelerinde çalışma sermayesi yönetim etkinliğinin incelenmesi amaçlanmıştır. Çalışma giriş bölümü dâhil altı başlıktan oluşmaktadır. İkinci başlıkta çalışma sermayesi yönetimi ve etkinliği kısaca açıklanmaktadır. Üçüncü başlıkta çalışma sermayesi konusunda yapılan çalışmaların özetlendiği literatür taramasına yer verilmektedir. Dördüncü başlıkta veri, örneklem, değişkenler ve çalışma sermayesi yönetimi etkinlik ölçümünde Bhattacharya (1997) tarafından geliştirilen endeks yöntemi açıklanmaktadır. Çalışma bulguları beşinci başlıkta sunulmaktadır. Bulgulardan yola çıkarak genel bir değerlendirme ve ilgili taraflara önerilerle çalışma sonlanmaktadır.

\section{2. ÇALIŞMA SERMAYESİ YÖNETIMI VE ETKINLİĞİ}

Bir işletmede varlıklar uzun vadede nakit akışı sağlayan sabit varlık yatırımları ve günlük faaliyetlerin sürdürülmesi için gereken çalışma sermayesi yatırımları toplamından oluşur. Çalışma sermayesi, işletme faaliyetlerinin sağlıklı bir şekilde yürütebilmesinde, iş hacminin ve kredibilitenin arttırılmasında önemlidir (Ceylan ve Korkmaz, 2018: 313). Çalışma sermayesini 
oluşturan cari (dönen) varlıklar, bir yıl içinde nakde dönüşmesi beklenen varlıklardır. Diğer bir ifadeyle, işletmenin sermaye harcamalarına bağlı olarak tesisin üretime başlayabilmesi ve faaliyetlerin sorunsuz bir şekilde yerine getirilmesi için gerekli olan sermayedir (Günay ve Böyükaslan, 2020: 259). Çalışma sermayesi yönetimi ise, nakit ve nakit benzeri hazır değer ve menkul kıymetler, alacaklar, stoklar ve bunlar dışındaki diğer dönen varlıklardan oluşan çalışma sermayesinin optimal düzeyinin belirlenmesi ve çalışma sermayesinin en düşük maliyetle finanse edilmesini içeren yatırım ve finansman kararlarını kapsamaktadır (Brigham ve Houston, 2009: 488; Moyer, McGuigan ve Kretlow, 2009: 550).

Likidite riskinin azaltılması amacıyla dönen varlıklara gereğinden fazla yatırım yapılması firma değerini artırmayacaktır (Ata ve Buğan, 2016: 30). Yüksek düzeyde çalışma sermayesi yatırımı işletmede atıl fonlara neden olarak (Karagözoğlu, Aktaş ve Kayalıdere, 2019: 238) bu varlıkların finansmanı nedeniyle finansman maliyetini arttıracak, işletme kârlılığını azaltacaktır. Ayrıca sermayenin firsat maliyeti sermayeden elde edilebilecek kârlılığın azalmasına neden olacaktır. Yetersiz çalışma sermayesi ise, işletmelerin likidite riskini artırabileceği gibi, kredi politikası nedeniyle oluşuyorsa işletmelerin ulaşabilecekleri satış gelirlerini düşürecektir. İşletmeler az stok tutma sayesinde firsat maliyetinin yanında depolama, sigorta, bozulma, modasının geçmesi gibi elde tutma maliyetlerinden kaçınırken (Ceylan ve Korkmaz, 2018: 314), yetersiz stoklar işletme gelirlerini etkileyebileceği gibi işletmede stok kalemlerine yönelik enflasyon nedeniyle ilave maliyetleri yaratabilmektedir. Dolayısıyla dönen varlık yatırımlarının azaltılması kararlarında çalışma sermayesi yetersizliğine neden olunmaması gerektiğinin bilinmesi gerekmektedir (Ata ve Buğan, 2016: 30).

Toplam varlıklar içerisinde dönen varlıkların payı, üretim işletmelerinde yüzde 50'lere kadar ulaşırken, toptan ve perakende ticaret işletmelerinde ise yaklaşık yüzde 70'lere ulaşmaktadır (Aydın, Başar ve Coşkun, 2018: 178). Çalışma sermayesi düzeyi faaliyet konusu farklılıklarının yanı sıra işletme büyüklüğü, faaliyette bulunduğu süre (işletme yaşı), kredili satış ve stok politikası, işletme üretim kapasitesi, ekonomik konjonktür, faaliyet gösterdiği bölge, mevzuat ve yönetici tutumları gibi birçok faktörden etkilenir (Aksoy ve Yalçıner, 2008: 69; Erdinç, 2008: 234). Çalışma sermayesi düzeyini etkileyen bu faktörlerle birlikte yönetim kararlarında bütün ve her bir dönen varlık unsur düzeyinin belirlenmesinde bu varlıkların finansmanıyla ilgili kaynak maliyeti ve işletme finansal yapısının dikkate alınması gerekmektedir.

Girdinin çıtıya dönüşüm sürecini yansıtan ve performans ölçüm ve değerlendirme aracı olarak (Karagözoğlu vd., 2019: 232) etkinlik, en fazla çıktıyı üretmek için en az girdinin kullanımı olarak tanımlanabilir (Yavuz, 2003: 2; akt. Karakaya, Kurtaran ve Dağl1, 2014: 4). Çalı̧̧ma sermayesi yönetim etkinliği ise, işletmenin vadesi gelen kısa vadeli yükümlülüklerini yerine getirememe riskini ortadan kaldırarak dönen varlıklara aşırı yatırım yapılmasını önleyecek şekilde dönen varlıkların ve finansmanında kullanılan kaynakların planlamasını ve kontrolünü kapsamaktadır (Ashraf, 2012: 21).

Etkin çalışma sermayesi yönetimi işletme kârlılığını arttırarak (Korkmaz ve Yaman, 2019: 314) firma değeri maksimizasyonu amacına ulaşılmasını sağlayacaktır (Ata ve Buğan, 2016: 30). Çalışma sermayesi yönetimi etkinliği, işletmelerin vadesi gelen yükümlülüklerini yerine getirebilmesine diğer ifadeyle likiditesinin korunarak kredibilitesinin artmasına, varlıkların düşük değerle satılarak işletme tasfiyesinin ve iflasla ilgili olası maliyetlerin önüne geçilmesine olanak sağlayacaktır (Moyer vd., 2009: 550). Çalışma sermayesi yönetiminde etkinliğin sağlanması, çalışma sermayesi unsurlarının her birinin etkinliğine dayalıdır (Erdinç, 2008: 234). Ayrıca işletme satış gelirlerinin arttırılması dönen varlık unsurlarının etkin bir şekilde 1414 
kullanımına dayanmaktadır. Çalışma sermayesi yatırım ve finansman politikaları ise bu hususlara uygun oluşturulmalıdır.

Çalışma sermayesi yönetimi etkinliğinin ölçümü ve değerlendirilmesinde çeşitli yöntemler bulunmaktadır. Dönen varlık kalemlerinin optimal düzeylerinin belirlenmesinde geliştirilen yöntem ve modellerin (Aksoy ve Yalçıner, 2008) yanı sıra bir bütün olarak çalışma sermayesi yönetiminin etkinliğinde oran analizi, matematiksel programlama yöntemleri, istatistiksel yöntemler, çok kriterli karar verme yöntemleri ve dengeli ölçüm kartı gibi diğer yöntemler kullanılmaktadır (Karakaya, Kurtaran ve Dağlı, 2014: 4-5). Bu şekilde genel gruplandırmanın dışında çalışma sermayesi yönetiminin işletme performansına etkilerinin incelenmesinde, net çalışma sermayesi, likidite oranları (Akbulut, 2011; Ashraf, 2012; Ata ve Buğan, 2016), nakit dönüş süresi (Deloof, 2003; Banos-Caballero vd., 2010; Akbulut, 2011; Ashraf, 2012; Korkmaz ve Yaman, 2019) en yaygın kullanılan yöntem ve değişkenlerdir.

Çalışma sermayesi yönetimi etkinliğinde likidite oranları işletmenin dönen varlık yatırım kararları ve kısa vadeli finansman kararlarının birlikte ele alınmasına dayalı olarak (Okka, 2009) işletmenin likidite riski yönetimine odaklanır. Net çalışma sermayesi ise dönen varlık ve kısa vadeli yabancı kaynakların oranlanması yerine farkının alınmasıyla hesaplanan ve işletmenin bir faaliyet döneminde yerine getirmesi gereken yükümlülüklerini karşılayabilme kabiliyetine kanıtlar sunar (Ceylan ve Korkmaz, 2018: 314). Çalışma sermayesi yönetiminde sık kullanılan diğer yöntem olan nakit dönüş süresi ise çalışma sermayesi yatırım (alacak ve stok) ve finansman (ticari borçlar) kararlarının satış ve satışların maliyeti gibi (Aydın vd., 2018: $100 ; 179)$ faaliyet sonuçlarıyla olan ilişkilerine dayalı olarak; yatırım, finansman kararları ve faaliyet sonuçları etkileşimine göre çalışma sermayesi yönetimini değerlendirme yöntemlerinden biridir (Deloof, 2003: 576).

Çalışma sermayesi yönetiminin başarısı, işletmenin diğer kararlarında başarıya ulaşmasının başlangıcı olarak nitelendirilebilir. İşletmelerin varlık yapısında finansman maliyetlerini, kur, faiz oranı, enflasyon riski ve operasyonel risk gibi riskleri göz önünde bulundurmadan çalışma sermayesi yatırım ve finansman politikasını belirlemesi katlandığı maliyetleri arttırarak kârlılıklarını düşürecek, zarar etmelerine ve firma değerinin azalmasına neden olacaktır. Bu nedenle çalışma sermayesi kararlarında etkinliğin sağlanması gerekirken, daha önce belirtilen yöntemler ilgili kalemlerin tek yıllık gözlemlerine dayalı olarak hesaplanmakta ve/veya yıllar itibariyle karşılaştırılmaktadır. Yönetim kararları etkinliği, yöneticilerin yaşanan değişime verdiği tepkilerin incelenmesi yoluyla daha doğru ölçülmesine imkân sağlar. İşletme faaliyetlerinde temel amaç, minimum girdi ile maksimum satış gelirlerine ulaşmak olduğundan, satışlardaki değişime çalışma sermayesi yatırım kararlarında yönetim etkinliğinin incelenmesi çalışma sermayesi yönetiminin daha hassas ölçümü ve değerlendirilmesine imkan sağlamaktadır. Bu yönüyle, Bhattacharya (1997) tarafından önerilen ve literatürde diğer yöntemlere kıyasla kısıtlı kullanıma sahip Endeks Yöntemi, satışlardaki değişim karşısında çalışma sermayesi yönetimi kapsamında yönetici tepkilerini birlikte ele alan ve aralarındaki ilişkilere dayalı olarak çalışma sermayesi yönetim etkinliğinin ölçümüne olanak sağlayan alternatif bir yöntemdir. Endeks yöntemi detaylı olarak dördüncü bölümde açıklanmakla birlikte sonraki başlıkta çalışma sermayesiyle ilgili literatür özetlenmektedir.

\section{LITERATÜR}

Günümüz rekabet şartları altında faaliyetlerin sürdürülmesi ve firma değerinin maksimizasyonu günlük işletme faaliyetlerinin etkin yönetimine bağlıdır. Etkin çalışma 
sermayesi yönetiminin önemi, çalışma sermayesinin kârlılık ve firma değeriyle ilişkilerinin incelendiği çalışmalarda ulaşılan sonuçlarda da öne çıkmaktadır. Çalışma sermayesiyle ilgili literatür incelendiğinde, çalışma sermayesi yönetiminin işletme kârlılığına ve firma değerine etkilerini inceleyen ampirik araştırmalara sıklıkla rastlanmaktadır. Çalışma sermayesi yönetimiyle kârlılık arasındaki ilişki, Belçika işletmelerinde (Deloof, 2003), küçük ve orta büyüklükteki işletmelerde (Garcia-Teruel ve Martinez-Solano, 2007), Pakistan Karaçi borsası işletmelerinde (Raheman ve Nasr, 2007), İstanbul borsasında işlem gören gıda, beyaz eşya ve elektronik, tekstil gibi çeşitli imalat sektörlerinde (Şen ve Oruç, 2009), Pakistan tekstil sektörü işletmeleri (Ali, 2011) örneklerinde incelenmiştir. Polonya gıda ve içecek imalat sektöründe (Bieniasz ve Golas, 2011), Hindistan örneğinde farklı sektör işletmelerinde (Ashraf, 2012), Nijerya borsasında işlem gören işletmeler (Barine, 2012) ve Finlandiya işletmeleri (Enqvist, Graham ve Nikkinen, 2014) ÇSY ve kârlılık ilişkisi incelenmiştir. Bu çalışmalarda genellikle nakit dönüş süresi ve oran yöntemleri kullanılmıştır.

Uluslararası ve ülkeler bazında turizmde yaşanan olumlu gelişmelerle doğru orantılı olarak turizm sektörü örnekleminde yapılan çalışmalar son yıllarda (Hiadlovský vd., 2016; Kendirli ve Çankaya, 2016; Helhel ve Karasakal, 2017; Korkmaz ve Yaman, 2019; Beyazgül ve Karadeniz, 2020) artarken, bu çalışmalarda çalışma sermayesinin işletme performansına etkileri sıklıkla konu edinilmektedir. Çalışma sermayesi düzeyini etkileyen unsurlar finans alanında yapılan çalışmalara (Appuhami, 2008; Banos-Caballero, Garcia-Teruel ve MartinezSolano, 2010; Gill ve Biger, 2013; Fiador, 2016) konularındandır. Ayrıca beklendiği üzere işletme iflas riskleriyle ilgili çalışmalarda da çalışma sermayesi yönetimi ile ilgili değişkenler dâhil edilmektedir (Beaver, 1966; Altman, 1968; Gentry, Newbold ve Whitford, 1984).

Çalışma sermayesi yönetimi ve etkinliğinin işletmeler açısından önemini ortaya koyan literatüre katkı sağlayan ve Bhattacharya (1997) tarafından geliştirilen endeks yöntemiyle yapılan çalışmalar son yıllarda artan ilgiyle literatürde yer bulmaktadır (Ghosh ve Maji, 2004; Afza ve Nazir, 2011; Valipour ve Jamshidi, 2012; Kaur ve Singh, 2013; Kavitha ve Shanmugam, 2015; Kasiran, Mohamad ve Chin, 2016; Marie ve Azhagaiah, 2017a; 2017b; Güler ve Konuk, 2019; Kandil Göker, 2018; 2020; Erem Ceylan, 2020). Endeks yöntemiyle çalışma sermayesi etkinliğini inceleyen çalışmalar sonraki paragraflarda kısaca özetlenmektedir.

Endeks yöntemiyle çalışma sermayesi yönetimi etkinliğini ölçen ilk çalışmalardan biri Ghosh ve Maji (2004) tarafından Hindistan çimento şirketlerinin 1992-2002 dönemi verilerinde gerçekleştirilmiştir. 20 işletmenin performans, kullanım ve etkinlik endekslerinin hesaplandığ1 ve sektör ortalamalarının endüstri normu olarak kabul edildiği çalışmada, işletmelerin endüstri normuna ulaşma durumları test edilmiştir. Bir bütün olarak değerlendirildiğinde incelenen dönemde Hindistan çimento sektörü işletmelerinin iyi bir performans göstermedikleri ve çalışma sermayesi yönetimi etkinliğinin zayıf olduğu tespit edilmiştir.

Ramachandran ve Janakiraman (2009) çalışma sermayesi yönetiminin işletmelerin faaliyet kârlılığına etkilerini 1997-2006 dönemde Hindistan kağıt sanayi işletmeleri örneğinde incelemiştir. Çalışma sermayesi etkinliğinin endeks yöntemiyle incelendiği çalışmada ortalama olarak sektörün çalışma sermayesi yönetiminde etkin olduğu bulgusuna ulaşılmıştır. Ayrıca çalışma sermayesi yönetiminin faiz ve vergi öncesi kâra etkilerinin incelendiği çalışmada nakit dönüş süresi, ticari borç devir süresi, alacak devir süresi ve stok devir süresi açıklayıcı değişken, finansal varlık oranı, kaldıraç oranı ve satışların logaritması kontrol değişkenleri olarak test edilmiştir. Regresyon yöntemiyle kurulan modelin analiz edildiği çalışmada Hint kağıt sanayi 1416 
işletmelerinde nakit dönüş süresinin FVÖK'e etkisinin negatif, ticari borç devir süresi ve alacak devir süresinin pozitif yönde etkili olduğu tespit edilmiştir. Stok devir süresinin ise anlamlı bir etkisi saptanmamıştır.

Afza ve Nazir (2011) Pakistan çimento sektörü çalışma sermayesi yönetimi etkinliğini 19882008 dönemi örnekleminde endeks yöntemiyle, Ghosh ve Maji (2004) gibi endüstri ortalamalarına dayalı olarak işletmelerin hedef çalışma sermayesi yönetimi etkinlik düzeyine ulaşma durumlarını incelemişlerdir. Çalışmada, Pakistan çimento sektörü işletmelerinin incelenen dönemde etkinlik düzeylerinin iyi olduğu tespit edilmiştir.

Valipour ve Jamshidi (2012) endeks yöntemi ve nakit dönüş süresini birlikte kullanılarak çalışma sermayesi etkinliğinin aktiflerin faaliyet kârlılığına olan etkilerini incelemişlerdir. Tahran borsasında işlem gören metal dışı imalat, ilaç, ana metal ve kimya sektörlerinde çalışma sermayesi etkinliğinin aktif kârlılığına etkileri 2000-2011 dönemi verilerinde incelenmiştir. Çalışmada, çalışma sermayesi performans, kullanım ve etkinlik endekslerinin tümünün kârlılığ pozitif etkilediği ve bu durumun tüm örneklemde ve incelenen tüm sektörlerde geçerli olduğu bulgusuna ulaşılmıştır. Elde edilen bu bulgu endeks yönteminin, ilgili çalışmalarda çalışma sermayesi yönetim etkinliği göstergesi olarak kullanılması gerektiğine kanıt sunar niteliktedir.

Kamau ve Basweti (2013) Nairobi menkul kıymetler borsası işletmelerinde kurumsal yönetim ve çalışma sermayesi yönetim etkinliği ilişkisini incelemişlerdir. 2006-2012 yıllarında Nairobi borsasında işlem gören 42 işletme örnekleminde endeks yöntemine göre belirlenen çalışma sermayesi etkinliğinde kurumsal yönetim ilişkisi panel veri regresyon yöntemiyle analiz edilmiştir. Kurumsal yönetim göstergesi olarak yönetici ikiliği, yönetim kurulu büyüklügüü, yönetici çalışma süresi, yönetici ücretleri gibi toplam altı değişken açıklayıcı değişken, işletme büyüklüğü, kârlılık ve kaldıraç oranı ise kontrol değişkeni olarak modele dahil edilmiştir. Analize dahil edilen hiçbir değişkenin çalışma sermayesi etkinliğinde anlamlı bir etkisi saptanmamıştır. Çalışmada, kurumsal yönetim ile çalışma sermayesi yönetimi etkinliği arasında ilişki olmadığı sonucuna ulaşmıştır.

Kaur ve Singh (2013) sermaye malı sektörlerinden 14 Hint işletmesinde endeks yöntemiyle ölçülen ÇSY etkinliğini ölçmeyi amaçladıkları çalışmada 2000-2010 döneminde 10 yıllık verileri kullanılmıştır. Elde edilen bulgular incelenen işletmelerin etkinliğinin zayıf olduğunu göstermektedir. Çalışma sermayesi etkinliğinde endüstri ortalamasının hedef çalışma sermayesi etkinlik düzeyi olarak kabul edilebileceğinin önerildiği çalışmada ayrıca etkinlik ve kârlılık arasındaki ilişki incelenmiştir. Endüstri ortalamalarının hedef çalışma sermayesi etkinlik düzeyi olarak kabul edilebileceği sonucunun yanı sıra endeks yöntemiyle ölçülen çalışma sermayesi etkinliğinin kârlılıkla ilişkili olduğu yönünde bulgulara ulaşılmıştır.

Kavitha ve Shanmugam (2015) Hindistan ilaç sektörü şirketlerinde çalışma sermayesi yönetim etkinliğini işletme ölçeği bazında incelemişlerdir. 2002-2012 yıllarını kapsayan araştırmada 10 yıllık çalışma sermayesi yönetim etkinliğinin endeks yöntemiyle hesaplandığı çalışmada büyük ve küçük ölçekli işletmelerin endüstri ortalamasıyla ölçülen hedef etkinlik düzeyine ulaşma durumları incelenmiştir. Küçük ölçekli işletmelerde çalışma sermayesi etkinlik düzeyinin artış yönlü bir eğilim gösterdiği, büyük ölçekli işletmelerin ise dalgalı bir seyir izlediği tespit edilmiştir. Çalışmada incelenen dönem itibariyle küçük ölçekli şirketlerin dönen varlık ve çalışma sermayesi yönetiminde büyük ölçekli işletmelere göre daha etkin oldukları sonucuna ulaşılmıştır. 
Malezya'da küçük ve orta büyüklükteki işletmelerin çalışma sermayesi etkinliğinin 2010-2013 döneminde Kasiran, Mohamad ve Chin (2016) tarafından incelendiği çalışmada işletmelerin çalışma sermayesi performans endeks düzeyleri ve buna bağlı olarak ÇSY etkinlik düzeylerinin düşük düzeyde kaldığı saptanmıştır. İşletmeler satışları arttırma amacıyla çalışma sermayesi kullanımında değişimlerin oransal olduğu ancak aynı başarıyı performans endeksiyle tespit edilen çalışma sermayesi kalemlerindeki değişime karşı satışlardaki değişimin düşük düzeyde kaldığı dolayısıyla etkin bir çalışma sermayesi yönetiminden söz edilemediği tespit edilmiştir.

Marie ve Azhagaiah (2017a) Hindistan'da demir-çelik sektörü işletmeleri ÇSY etkinliğini 2005-2017 döneminde incelemişlerdir. Endüstri ortalamasının hedef ÇSY etkinlik düzeyi olarak kabul edildiği çalışmada en küçük kareler yöntemiyle işletme bazında hedef etkinlik düzeyine ulaşıp ulaşmadığı incelenmiştir. Analiz edilen işletmelerin performans, kullanım ve etkinlik düzeylerinin hedef çalışma sermayesi etkinlik düzeyiyle anlamlı pozitif yönde ilişkili olduğu dolayısıyla işletmelerin incelenen dönemde çalışma sermayesi yönetiminin etkin olduğu tespit edilmiştir. Yine Marie ve Azhagaiah (2017b) tarafindan Hindistan hızlı tüketim ürünleri sektörü işletmelerinde 2003-2015 döneminde ÇSY etkinliği endeks yöntemiyle incelenmiştir. Çalışma bulguları incelenen işletmelerin çalışma sermayesi yönetiminin etkin olduğunu göstermektedir.

Endeks yöntemiyle çalışma sermayesi etkinliğinin Türkiye örnekleminde ilk kez uygulandığı çalışma olan Kandil Göker (2018)'in 24 gıda sektörü işletmesinde 2010-2017 dönemi ÇSY etkinlik düzeyleri incelenmiştir. Elde edilen bulgular 8 yıllık etkinlik endeks değeri ortalamalarına göre işletmelerin çalışma sermayesi yönetiminin etkin olduğunu göstermektedir. Türkiye özelinde yapılan öncü çalışmalardan biri olan ve Güler ve Konuk (2019) tarafından 2009-2016 yıllarında verileri süreklilik arz eden 21 işletmenin çeyrek dönemlik gözlemlerinde ÇSY etkinliği incelenmiştir. Çalışma bulguları incelenen dönemde ortalamada işletmelerin performans ve kullanım endekslerinin büyük oranda başarılı olduğu sonuç olarak ÇSY'de etkin olduklarını göstermektedir. Erem Ceylan (2020) ise Borsa İstanbul'da işlem gören 8 perakende ticaret sektörü işletmesinin 2010-2019 dönemi çalışma sermayesi yönetimi etkinliğini ölçmüştür. Çalışma bulguları perakende ticaret sektörü işletmelerinin çalışma sermayesi yönetiminde etkin olduklarını göstermektedir. Analiz edilen üç işletmenin kullanım endeksinin satışların arttırılmasında dönen varlıkların başarılı şekilde yönetilmediğini göstermekle birlikte performans endeksindeki başarı çalışma sermayesi yönetiminin bütün olarak etkin olmasını sağladığı tespit edilmiş̧tir. Yine Türkiye örnekleminde Kandil Göker (2020) tarafından yapılan çalışmada Borsa İstanbul sürdürülebilirlik endeksinde listelenen 19 işletmenin sürdürülebilirlik endeksinin oluşturulduğu 2014 öncesi ve sonrası olmak üzere 2010-2013 ve 2015-2018 dönemi ÇSY etkinliği ölçülmektedir. Ayrıca işletmelerin sürdürülebilirlik endeksi öncesi ve sonrası dönem açısından ÇSY etkinliğinin farklılı̆̆ analiz edilmiştir. Çalışma bulguları işletmelerin endeks öncesi ve sonrası etkinliklerinin istatistiksel olarak anlamlı düzeyde farklılaştığını ve sürdürülebilirlik endeksi sonrası dönemde işletmelerin çalışma sermayesi yönetim etkinliğinin düştüğünü, özellikle çalışma sermayesinin satış arttırma yönlü kullanılamadığını göstermektedir.

\section{YÖNTEM}

\section{1. Çalış̧ma Amacı, Veri ve Örneklem}

$\mathrm{Bu}$ çalışmada Borsa İstanbul turizm endeksinde listelenen lokanta ve oteller ile havayolu ulaştırma işletmelerinde, çalışma sermayesi etkinliğinin endeks yöntemiyle ölçülerek 1418 
değerlendirilmesi amaçlanmıştır. Uluslararası turizmden aldığg pay ile Türkiye ekonomisinde önemli yer tutan turizm sektörü yatırımlarının etkin yönetimi kaynak kullanım etkinliğini sağlamaktadır. Yiyecek içecek, konaklama ve havayolu ulaştırma işletmelerinin performans ve başarıları, risklere duyarlılıkları nedeniyle faaliyet dönemi yönetim kararlarından etkilenmektedir. Çalışma sermayesi yönetiminde etkinliğin sağlanması işletmenin satış düzeyinden finansman maliyetine kadar birçok noktada etkisi vardır. Sonuç olarak bu etkiler işletme performans ve başarısının belirleyicisi olabilmektedir.

Çalışma sermayesi yönetimi ile ilgili literatürde sıkça kullanılan yöntemlerin dışında Bhattacharya (1997) tarafından geliştirilen Endeks Yöntemi, yöneticilerin faaliyetlerdeki değişime karşı çalışma sermayesi yatırım kararlarının etkinliğini incelemeyi amaçlayan bir yöntemdir. Diğer ifadeyle işletme faaliyet sonuçları olan satışlarla işletme yöneticilerinin çalışma sermayesi yönetim kararlarında ne düzeyde etkin olduklarını belirlemeyi ve incelemeyi amaçlamaktadır. $\mathrm{Bu}$ çalışmada, çalışma sermayesi yatırım kararları etkinliğinin incelenmesinde dönen varlık kalemleri dört grup incelenmiştir ve bu gruplar Tablo 1'de gösterilmiştir.

Tablo 1. Dönen Varlık Unsurları ve Çalışmada Alınan Gruplar

\begin{tabular}{|c|c|}
\hline Dönen Varlıklar & Gruplar \\
\hline $\begin{array}{l}\text { 1. Nakit ve Nakit Benzerleri } \\
\text { 2. Finansal Yatırımlar }\end{array}$ & $\begin{array}{l}\text { Hazır Değer ve Menkul Kiymetler } \\
\qquad(1+2)\end{array}$ \\
\hline $\begin{array}{ll}\text { 3. } & \text { Ticari Alacaklar } \\
\text { 4. } & \text { Diğer Alacaklar }\end{array}$ & $\begin{array}{c}\text { Alacaklar } \\
(3-4)\end{array}$ \\
\hline 5. Stoklar & $\begin{array}{c}\text { Stoklar } \\
(5)\end{array}$ \\
\hline $\begin{array}{ll}\text { 6. } & \text { Türev Varlıklar } \\
\text { 7. } & \text { Peşin Ödenmiş Giderler } \\
\text { 8. } & \text { Dönem Vergi Yükümlülükleri } \\
\text { 9. } & \text { Diğer Dönen Varlıklar }\end{array}$ & $\begin{array}{l}\text { Diğer Dönen Varlıklar } \\
\qquad(6+7+8+9)\end{array}$ \\
\hline
\end{tabular}

Çalışmada, payları borsada işlem gören, verileri analize uygun olan 9 yiyecek içecek ve konaklama işletmesi ile 2 havayolu ulaştırma işletmesi olmak üzere 11 işletmenin 2009-2019 dönemi yıllık verilerinde çalışma sermayesi yönetim etkinliği incelenmiştir. Çalışmada kullanılan veriler, Kamuyu Aydınlatma Platformu'nda açıklanan işletme finansal raporlarından derlenmiştir. Kullanılan endeks yöntemi, detaylı olarak alt başlıkta açıklanmakla birlikte endeks yöntemine göre hesaplanan bulgulara beşinci başlıkta yer verilmiştir.

\subsection{Endeks Yöntemi}

Bhattacharya tarafından 1997 y1lında geliştirilen "Endeks Yöntemi”, çalışma sermayesi yönetimi etkinliğinin ölçümünde mevcut yöntemlere bir alternatif olarak çalışma sermayesi yatırım kararları etkinliğinin ölçümü ve izlenmesini sağlamaktadır. Endeks yönteminde, faaliyet sonuçları olan satışlarla çalışma sermayesi yatırım kararları ilişkisinden hareketle çalışma sermayesi yönetim etkinliği ölçülerek değerlendirilmektedir. Ayrıca, finans yöneticisinin sorumluluğunda olan diğer fonksiyonlar açısından da uygulanabilen (Bhattacharya, 2007: 212) endeks yöntemi, çalışma sermayesi yönetimi etkinliğinin ölçümünde oran ya da nakit dönüş süresi gibi yöntemlere bir alternatiftir. Sözü edilen yöntemlerle birlikte 
kullanılabileceği gibi, satışlardaki değişime karşı yöneticilerin çalışma sermayesi yatırım kararlarında ne derece etkin olduğunu ortaya koymaktadır.

Çalışma sermayesi yönetim etkinliğinin sağlanması çalışma sermayesi unsurlarının her birinde etkinliğin sağlanmasıyla mümkündür (Erdinç, 2008: 234). Dolayısıyla henüz fazla kullanılmamakla birlikte çalışma sermayesi yönetimi etkinliğinde ve işletme performansına çalışma sermayesinin etkilerinin incelenmesinde endeks yöntemi, gerek bütün olarak çalışma sermayesini gerekse her bir unsurun hesaplamalara dahil edilmesi nedeniyle anlamlı sonuçlar ortaya koymaktadır. Ayrıca, Valipour ve Jamshidi (2012: 207-208) yaptıkları çalışmada, işletmelerin aktif kârlılığında endeks yöntemiyle ölçülen çalışma sermayesi yönetim etkinliğinin kullanılabileceğini, Kaur ve Singh (2013: 354) ise endeks yöntemiyle ölçülen etkinliğin aktif kârlılığı ile pozitif ilişkili olduğunu tespit etmiştir. Endeks Yöntemi'ne göre çalışma sermayesi yönetimi etkinliği, aşağıda açıklanan süreç adımlarının izlenmesiyle hesaplanmaktadır (Bhattacharya, 2007: 218-220).

Birinci Adım Performans Endeksi: Performans Endeksi (PI), her bir çalışma sermayesi unsurunun ayrı ayrı veya bütün olarak çalışma sermayesi performansının ölçümü ve izlenmesini sağlamaktadır (Bhattacharya, 2007: 219). Her bir çalışma sermayesi kalemi için ayrı ayrı performans endeksi hesaplanabileceği gibi bütün çalışma sermayesi kalemlerinin dâhil edildiği genel performans endeksi hesaplanabilmektedir. Genel performans endeksi Formül 1 'deki şekilde hesaplanmaktadır.

$$
P I_{i}=\frac{I_{s} \sum_{i=1}^{N} \frac{W_{i, t-1}}{W_{i, t}}}{N}
$$

Formül 1'de;

$I_{s}: \mathrm{S}$ satışlar olmak üzere $\mathrm{S}_{\mathrm{t}} / \mathrm{S}_{\mathrm{t}-1}$ şeklinde hesaplanan satış endeksini,

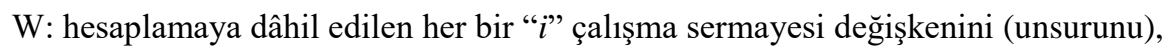

$\mathrm{N}$ : analize dahil edilen çalışma sermayesi değişken sayısını $\left(\mathrm{W}_{1}, \ldots, \mathrm{W}_{\mathrm{N}}\right)$ göstermektedir.

Tek başına performans endeksi çalışma sermayesi unsurlarının ayrı ayrı değerlendirilmesi ve karşılaştırılması istendiğinde anlamlıdır. İncelenen çalışma sermayesi unsurlarından birinin düzeyi arttığında, ilgili kalemin ağırlığı nedeniyle küçük tutarlı kalemlerin etkisini düşürmektedir. $\mathrm{Bu}$ ise tek başına genel performans endeks değeriyle ÇSY etkinliğinin değerlendirilmesinde yanıltıcı olmaktadır (Bhattacharya, 2007: 216). Hesaplanan genel performans endeks değerinin 1'den büyük olması çalışma sermayesi yönetim performansının etkinliğini (Ghosh ve Maji, 2004), 1'den küçük olması ise performansın yetersiz olduğunu gösterir. Tek başına performans endeksiyle çalışma sermayesi yönetiminin bütünü hakkında değerlendirme yapılması yetersiz ve hatalıdır. Performans endeksi tek başına yanıltıcı olacağından çalışma sermayesi yönetim etkinliğinin ölçümünde ikinci adımda kullanım endeksi hesaplanmaktadır.

Íkinci Adım Kullanım Endeksi: Kullanım endeksi (UI), varlık kullanım etkinliğindeki değişimi diğer ifadeyle dönemler itibariyle satışlardaki değişime karşı dönen varlık yatırımlarındaki toplam değişimi, böylece bir bütün olarak satış yaratmak amacıyla yöneticilerin çalışma sermayesi kullanım durumlarını ölçerek değerlendirmeye imkan sağlamaktadır. Performans endeksi, dönen varlıkların bileşenlerinin yönetilmesindeki ortalama genel performansı gösterirken, kullanım endeksi, firmanın mevcut dönen varlıklarını bir bütün 1420 
olarak satış yaratmak amacıyla kullanma yeteneğini gösterir (Ghosh ve Maji, 2004). Satışlardaki değişime karşı yöneticilerin çalışma sermayesi yönetim kararlarındaki davranışlarını gösteren kullanım endeksinin amacı, elde edilen satış düzeyi için ne düzeyde çalışma sermayesinin kullanıldığını ölçmektir. Kullanım endeksi Formül 2'de gösterildiği şekilde hesaplanmaktadır (Bhattacharya, 2007: 220):

$$
U I_{i}=\frac{A_{t-1}}{A_{t}}
$$

Formül 2'de $A_{t}$ : $t$ dönemi için Cari Varlıklar ${ }_{t}$ / Satışlar ${ }_{t}$ olup, hesaplanan kullanım endeksi ardıl iki dönemde işletme satışlarına karşın ne düzeyde çalışma sermayesi kullanıldığını ölçmektedir. Kullanım endeksi, yöneticilerin çalışma sermayesi yatırım kararlarının nasıl şekillendiğini ve bu sayede işletme satış performansına etkisini göstermektedir. Genel yorum olarak daha düşük çalışma sermayesi kullanımıyla aynı düzeyde satış geliri elde ettiğini ya da aynı düzeyde çalışma sermayesi kullanımıyla daha yüksek satış geliri elde ettiğini gösterdiğinden kullanım endeksinin 1'den büyük olması beklenmektedir.

Üçüncü Adım Etkinlik Endeksi: Tek başına performans veya kullanım endeksi çalışma sermayesi yönetimi etkinliğini göstermemektedir. Çalışma sermayesi yönetim etkinliğinin ölçülebilmesi için performans endeksi ve kullanım endeksinin çarpılmasıyla elde edilen değerin dikkate alınması gerekir. Etkinlik Endeksi (EI) Formül 3'te gösterildiği şekilde hesaplanmaktadır (Bhattacharya, 2007: 220);

$$
E I_{i, t}=P I_{i, t} x U I_{i, t}
$$

Etkinlik endeksi, işletmenin çalışma sermayesi performans endeksi ile kullanım endeksinin bir sonucudur. Performans ve kullanım endeksinin çarpımıyla, çalışma sermayesi yönetiminin toplam etkinliği ölçülebilmektedir.

Endeks yöntemiyle ulaşılan endeks düzeylerinin oluşumu ve değerlendirilmesi için olası durumlar kapsamında incelemelerin yapılması ilgili paydaşlara fayda sağlayacaktır. Bu kapsamda satışlardaki ve tüm kalemler için çalışma sermayesindeki değişimin her iki yönde de eşit oranda olduğu durumlarda etkinlik endeksi 1 değerini alır. Bu durumda EI yanında genel performans endeksi ve kullanım endeksi 1 değerini alır. Genel olarak endeks değerlerinin 1'den büyük olması olumlu iken, 1 'in altında gerçekleşmesi çalışma sermayesi yönetim etkinliğinin düştüğünü gösterir.

Etkinlik endeksinin 1'den büyük olması bir önceki yıla göre;

I. aynı çalışma sermayesi düzeyinde daha fazla satışın gerçekleştiği " $\Delta W C_{1, \ldots, N}=$ $0 ; \Delta S>0$ ";

II. aynı satış düzeyine daha düşük çalışma sermayesiyle ulaşıldığı " $\Delta S=0 ; \Delta W C_{l}$, $\ldots, N<0$ ";

III. oransal olarak satışlardaki azalış düzeyinin en azından herhangi bir çalışma sermayesi kalemindeki azalıştan daha düşük düzeyde olduğu " $\% \Delta S<\% \Delta W C_{l, \ldots}$ ,$N$ ",

IV. oransal olarak satışlardaki artış düzeyinin en azından herhangi bir çalışma sermayesi kalemindeki artıştan daha yüksek düzeyde olduğu "\% $\% S>\% \Delta W C_{l, \ldots}$ ,$N "$ 
durumlarına bağlıdır. Genel olarak tersi durumlarda ise etkinlik endeksi 1 'in altında gerçekleşecektir ve bu durum işletmenin çalışma sermayesi yönetim etkinliğinin düştüğünü gösterir. Endeks yöntemine göre çalışma sermayesi ve satışlardaki değişim durumlarına göre performans, kullanım ve etkinlik endekslerindeki sonuçlar Tablo 2'de gösterildiği şekilde gerçekleşir.

Tablo 2. Etkinlik Endeksi Yönteminde Olası Durumlar, Koşullar ve Sonuçlar

\begin{tabular}{|c|c|c|c|c|c|c|}
\hline & \multicolumn{2}{|c|}{ Durum } & \multirow[b]{2}{*}{ Koșul } & \multicolumn{3}{|c|}{ Sonuç } \\
\hline & Satişlar & Çalışma Sermayesi & & PI & UI & EI \\
\hline 1 & $\Delta S=0$ & $\Delta W C_{N}=0$ & & $\mathrm{PI}=1$ & $\mathrm{UI}=1$ & $\mathrm{EI}=1$ \\
\hline 2 & $\Delta S=0$ & $\Delta W C_{N}<0$ & & $\mathrm{PI}>1$ & $\mathrm{UI}>1$ & EI $>1$ \\
\hline 3 & $\Delta S=0$ & $\Delta W C_{N}>0$ & & $\mathrm{PI}<1$ & $\mathrm{UI}<1$ & $\mathrm{EI}<1$ \\
\hline 4 & $\Delta S<0$ & $\Delta W C_{N}>0$ & & $\mathrm{PI}<1$ & $\mathrm{UI}<1$ & $\mathrm{EI}<1$ \\
\hline 6 & $\Delta S>0$ & $\Delta W C_{N}<0$ & & $\mathrm{PI}>1$ & $\mathrm{UI}>1$ & $\mathrm{EI}>1$ \\
\hline 5 & $\Delta S<0$ & $\Delta W C_{N}=0$ & & \multicolumn{2}{|c|}{$\mathrm{PI}=\mathrm{UI}<1$} & $\mathrm{EI}<1$ \\
\hline 7 & $\Delta S>0$ & $\Delta W C_{N}=0$ & & \multicolumn{2}{|c|}{$\mathrm{PI}=\mathrm{UI}>1$} & $E I>1$ \\
\hline $8^{*}$ & $\Delta S<0$ & $\Delta W C_{N}<0$ & $\% \Delta S>\% \Delta W C_{N}$ & $\begin{array}{l}\mathrm{PI}<1 \\
\mathrm{PI}>1\end{array}$ & $\mathrm{UI}<1$ & $\begin{array}{l}\mathrm{EI}<1 \\
\mathrm{EI}>1\end{array}$ \\
\hline $9^{*}$ & $\Delta S<0$ & $\Delta W C_{N}<0$ & $\% \Delta S<\% \Delta W C_{N}$ & $\begin{array}{l}\mathrm{PI}<1 \\
\mathrm{PI}>1\end{array}$ & $\mathrm{UI}>1$ & $\begin{array}{l}E I<1 \\
E I>1\end{array}$ \\
\hline $10^{*}$ & $\Delta S<0$ & $\Delta W C_{N}<0$ & $\% \Delta S=\% \Delta W C_{N}$ & $\begin{array}{l}\mathrm{PI}<1 \\
\mathrm{PI}>1\end{array}$ & $\mathrm{UI}=1$ & $\begin{array}{l}\mathrm{EI}<1 \\
\mathrm{EI}>1\end{array}$ \\
\hline $11^{*}$ & $\Delta S>0$ & $\Delta W C_{N}>0$ & $\% \Delta S<\% \Delta W C_{N}$ & $\begin{array}{l}\mathrm{PI}<1 \\
\mathrm{PI}>1\end{array}$ & $\mathrm{UI}<1$ & $\begin{array}{l}\mathrm{EI}<1 \\
\mathrm{EI}>1\end{array}$ \\
\hline $12^{*}$ & $\Delta S>0$ & $\Delta W C_{N}>0$ & $\% \Delta S>\% \Delta W C_{N}$ & $\begin{array}{l}\mathrm{PI}<1 \\
\mathrm{PI}>1\end{array}$ & $\mathrm{UI}>1$ & $\begin{array}{l}E I<1 \\
E I>1\end{array}$ \\
\hline $13^{*}$ & $\Delta S>0$ & $\Delta W C_{N}>0$ & $\% \Delta S=\% \Delta W C_{N}$ & $\begin{array}{l}\mathrm{PI}<1 \\
\mathrm{PI}>1\end{array}$ & $\mathrm{UI}=1$ & $\begin{array}{l}E I<1 \\
E I>1\end{array}$ \\
\hline
\end{tabular}

Genel olarak, satışlar ve çalışma sermayesi kalemlerindeki oransal değişim düzeyi, ilgili endekslerin yönünü belirlemektedir. Satışlardaki artışa karşı çalışma sermayesindeki artış düzeyinin daha düşük ya da azalış yönlü olması oransal değişime bağlı olarak tüm endekslerin 1 'den büyük olmasını sağlamakta bu ise etkinliğe işaret etmektedir. Satışlardaki azalışa karşı çalışma sermayesindeki azalış düzeyinin daha düşük ya da çalışma sermayesinin artış yönlü olması tüm endekslerin 1'in altında olmasına neden olmakta, bu durum ise etkinliğin sağlanamadığına işaret etmektedir.

Endeks yönteminde performans endeksi, satış düzeyindeki artışa karşı aynı ya da daha düşük çalışma sermayesi yatırımıyla ulaşılması nedeniyle işletme performansının olumlu olmasına, kullanım endeksinin ise aynı ya da daha yüksek satış için daha az çalışma sermayesi kullanıldı̆̆ını göstermektedir. Performans endeksi, çalışma sermayesi bileşenlerinin yönetilmesinde ortalama genel performansı gösterirken, kullanım endeksi işletmenin mevcut varlıklarını bir bütün olarak satış artırma amacıyla kullanım yeteneğini gösterir (Ghosh ve Maji, 2004; Kaur ve Singh, 2013; 348). Çalışma sermayesindeki toplam artış karşısında, satışlarda oransal olarak daha büyük artışla sonuçlandığında bu durum dönen varlık kullanım düzeyinin arttığını göstermektedir (Ghosh ve Maji, 2004; Kaur ve Singh, 2013; 348). Nihai olarak ortalama performans ve kullanım endekslerinin sonucu olan etkinlik endeksinin 1 'in üstünde olmasıyla etkinliğin sağlandığı yönünde bilgi sağlamaktadır. 


\section{BULGULAR}

Yapılan bu çalışmada Borsa İstanbul'da payları işlem gören yiyecek içecek, konaklama ve havayolu ulaştırma işletmelerinin 2009-2019 dönemi çalışma sermayesi yönetim etkinlikleri endeks yöntemiyle incelenmiştir. Yıllık düzenli verisi bulunan lokantalar ve oteller sektör sınıfından 9 işletmenin, havayolu ulaştırma sektör sınıfından 2 işletmenin; satış, performans, kullanım ve etkinlik endeks değerleriyle sektörler bazında ortalama endeks değerleri hesaplanarak Tablo 3 ve 4'te sunulmuştur.

Yiyecek içecek ve konaklama işletmelerinde inceleme döneminde satış endeks değeri en düşük \%3 ile 2012 yılı AVTUR işletmesinde, en yüksek ise 6,21 ile 2017 yılında TEKTU işletmesinde gözlenmiştir. Yıllar itibariyle ortalama satış endeksi ise 0,91 ile 2.11 arasında değişmektedir. Yiyecek içecek ve konaklama işletmelerinde 2012, 2014 ve 2016 yıllarında bir önceki yıla kıyasla satışlarda azalış $(\mathrm{SI}<1)$ gözlenirken diğer 7 yılda satış endeksi 1 'in üzerinde gerçekleşmiş, diğer ifadeyle satışlarda artış yaşanmıştır.

Performans endeks sonuçları, satışların azaldığ 1 dönemlerde çalışma sermayesi kalemlerinde yönetim kararlarının bu daralmayla uyumlu (PI>1) şekilde verildiğine (örn. ETILR: 2015; MAALT: 2013; MARTI: 2014) işaret etmektedir. En düşük performans endeksinin, 0,03 (\%3) ile AVTUR'un 2012 yılı gözleminde, en yüksek performans endeks değeri ise 206,88 ile MERIT işletmesinin 2016 y1lı gözleminde gerçekleşmiştir. Sektör işletmelerinin ortalama performans endeks değerleri 0,88 (2010 yılı) ile 23.71 (2016) aralığında değişmektedir. Ortalama performans endekslerine göre işletmelerin 2010 y1lı dışında çalışma sermayesi performans endeksinin 1'den büyük olması işletmelerin satışlardaki değişimler karşısında kalemler bazında aldıkları kararlarının olumlu olduğunu göstermektedir.

İşletmelerin kullanım endeks değerleri incelendiğinde en düşük kullanım endeks düzeyi 0,04 ile AVTUR'un 2012 yılında en yüksek kullanım endeks düzeyinin 4.75 ile 2017 yılında TEKTU işletmesinde gerçekleşmiştir. Buna karşın sektörün ortalama kullanım endeks değerleri 0.61 ile 2.10 arasında değişmektedir. 10 yılın 4'ünde kullanım endeks değeri 1 'in üzerindeyken bütün olarak çalışma sermayesi kullanımının işletme satışlarını desteklemediği ve atıl cari varlıkların olduğunu göstermektedir. Bu durumun işletme performansını ve kârlılığını olumsuz etkileyeceği ifade edilebilir. Ortalama değerler kapsamında performans ve kullanım endekslerinde elde edilen bu sonuçlar Hindistan'da sermaye malları işletmelerinde gözlenen, çalışma sermayesi kalemi bazlı performansın, satışları arttırmada bütüncül olarak çalışma sermayesi kullanım başarısıyla desteklenemediği bulgusuna benzemektedir (Kaur ve Singh, 2013: 351).

Çalışma sermayesi yönetimi etkinlik endeks değerleri incelendiğinde en düşük etkinlik endeksinin 0.001 ile 2012 yılında AVTUR'da, en yüksek etkinlik endeksinin ise 262.54 ile 2016 y1lı MERIT işletmesinde gerçekleştiği gözlenmiştir. Ortalama etkinlik endeks değerleri incelendiğinde 10 yılın 9'unda etkinlik değeri 1'in üzerinde gerçekleşmiş olup, en düşük 0.53 ile 2010 yılında en yüksek etkinlik ise 22.92 ile 2017 yılında gerçekleşmiştir. 
Tablo 3. Lokanta - otel sektör sınıfı işletmeleri çalıșma sermayesi yönetimi etkinlik değerleri

\begin{tabular}{|c|c|c|c|c|c|c|c|c|c|c|c|c|}
\hline İşletme & Endeks & 2010 & 2011 & 2012 & 2013 & 2014 & 2015 & 2016 & 2017 & 2018 & 2019 & $\underset{>1}{n}$ \\
\hline \multirow{4}{*}{ AYCES } & $S I$ & 1.33 & 1.31 & 1.10 & 1.12 & 1.07 & 1.09 & 0.74 & 1.30 & 1.46 & 1.28 & $9 / 10$ \\
\hline & $P I$ & 1.12 & 0.75 & 1.26 & 1.10 & 1.67 & 1.06 & 0.65 & 1.50 & 1.07 & 1.30 & $8 / 10$ \\
\hline & $U I$ & 0.79 & 0.46 & 1.31 & 1.05 & 1.82 & 0.99 & 0.62 & 1.43 & 1.05 & 1.20 & $6 / 10$ \\
\hline & $E I$ & 0.89 & 0.34 & 1.65 & 1.15 & 3.04 & 1.05 & 0.40 & 2.14 & 1.12 & 1.57 & $7 / 10$ \\
\hline \multirow{4}{*}{ AVTUR } & SI & - & 0.12 & 0.03 & 1.47 & 1.27 & 0.99 & 1.02 & 1.23 & 1.54 & 1.07 & $6 / 9$ \\
\hline & $P I$ & - & $0.08^{*}$ & $0.03^{*}$ & $1.22^{*}$ & 0.80 & 2.02 & 1.61 & 13.48 & 1.77 & 1.98 & $6 / 9$ \\
\hline & $U I$ & - & 0.18 & 0.04 & 1.07 & 0.09 & 4.41 & 1.89 & 2.17 & 0.20 & 1.41 & $5 / 9$ \\
\hline & $E I$ & - & 0.01 & 0.001 & 1.31 & 0.07 & 8.94 & 3.05 & 29.20 & 0.36 & 2.79 & $5 / 9$ \\
\hline \multirow{4}{*}{ ETILR } & $S I$ & - & - & - & 0.28 & 0.80 & 0.71 & 2.76 & 1.08 & 1.28 & 0.77 & $3 / 7$ \\
\hline & $P I$ & - & - & - & 0.28 & 17.66 & 44.94 & 0.88 & 1.89 & 3.40 & 1.14 & $5 / 7$ \\
\hline & $U I$ & - & - & - & 0.33 & 3.33 & 0.46 & 2.66 & 2.56 & 0.80 & 1.25 & $4 / 7$ \\
\hline & $E I$ & - & - & - & 0.09 & 58.83 & 20.58 & 2.34 & 4.84 & 2.71 & 1.42 & $6 / 7$ \\
\hline \multirow{4}{*}{ MAALT } & $S I$ & 1.45 & 1.20 & 0.76 & 0.50 & 0.84 & 1.24 & 0.35 & 2.67 & 0.71 & 1.08 & $5 / 10$ \\
\hline & $P I$ & 1.04 & 2.05 & 0.80 & 2.54 & 0.89 & 1.21 & 0.29 & 6.91 & 1.06 & 0.89 & $6 / 10$ \\
\hline & $U I$ & 0.47 & 0.46 & 0.51 & 0.63 & 0.60 & 0.89 & 0.31 & 2.12 & 0.19 & 0.96 & $1 / 10$ \\
\hline & $E I$ & 0.49 & 0.94 & 0.41 & 1.60 & 0.54 & 1.08 & 0.09 & 14.62 & 0.21 & 0.86 & $3 / 10$ \\
\hline \multirow{4}{*}{ MARTI } & $S I$ & 1.23 & 1.36 & 1.09 & 1.18 & 0.90 & 0.96 & 0.51 & 1.37 & 2.07 & 1.26 & $7 / 10$ \\
\hline & PI & 0.72 & 1.31 & 1.53 & 1.37 & 1.03 & 1.89 & 0.59 & 1.44 & 1.47 & 1.51 & $8 / 10$ \\
\hline & $U I$ & 0.76 & 1.26 & 0.95 & 1.37 & 0.87 & 1.86 & 0.37 & 2.06 & 0.72 & 1.49 & $5 / 10$ \\
\hline & $E I$ & 0.55 & 1.64 & 1.46 & 1.89 & 0.90 & 3.52 & 0.22 & 2.97 & 1.06 & 2.25 & $7 / 10$ \\
\hline \multirow{4}{*}{ MERIT } & SI & 1.28 & 0.93 & 1.44 & 4.42 & 0.99 & 1.10 & 1.42 & 1.28 & 0.93 & 1.44 & $7 / 10$ \\
\hline & $P I$ & $1.39^{*}$ & $0.80^{*}$ & $0.88^{*}$ & $2.61^{*}$ & $2.30^{*}$ & $0.85^{*}$ & $206.88^{*}$ & $1.39^{*}$ & $0.80^{*}$ & $0.88^{*}$ & $5 / 10$ \\
\hline & $U I$ & 0.65 & 0.91 & 0.86 & 1.04 & 2.56 & 0.52 & 1.27 & 0.65 & 0.91 & 0.86 & $3 / 10$ \\
\hline & EI & 0.91 & 0.72 & 0.76 & 2.72 & 5.89 & 0.44 & 262.54 & 0.91 & 0.72 & 0.76 & $3 / 10$ \\
\hline \multirow{4}{*}{ PKENT } & $S I$ & 1.04 & 1.27 & 1.02 & 1.01 & 1.05 & 1.07 & 0.57 & 1.92 & 2.01 & 1.31 & $9 / 10$ \\
\hline & $P I$ & 0.78 & 0.77 & 3.64 & 0.81 & 5.93 & 0.70 & 0.76 & 3.31 & 1.73 & 2.62 & $5 / 10$ \\
\hline & $U I$ & 0.79 & 0.71 & 2.06 & 0.73 & 1.37 & 0.78 & 0.75 & 1.50 & 0.64 & 2.16 & $4 / 10$ \\
\hline & EI & 0.62 & 0.54 & 7.49 & 0.59 & 8.14 & 0.54 & 0.56 & 4.96 & 1.11 & 5.67 & $5 / 10$ \\
\hline \multirow{4}{*}{ TEKTU } & $S I$ & 1.59 & 1.10 & 0.95 & 1.43 & 0.94 & 1.36 & 0.14 & 6.21 & 1.85 & 1.44 & $7 / 10$ \\
\hline & $P I$ & 0.36 & 3.52 & 7.79 & 1.73 & 0.61 & 1.36 & 0.42 & 9.26 & 3.25 & 1.84 & $7 / 10$ \\
\hline & $U I$ & 0.11 & 1.13 & 1.28 & 1.26 & 0.57 & 0.69 & 0.15 & 4.75 & 2.74 & 1.28 & $6 / 10$ \\
\hline & EI & 0.04 & 3.97 & 10.00 & 2.17 & 0.35 & 0.94 & 0.06 & 44.03 & 8.90 & 2.36 & $6 / 10$ \\
\hline \multirow{4}{*}{ UTPYA } & $S I$ & 0.97 & 1.51 & 0.86 & 1.11 & 1.09 & 0.90 & 0.65 & 1.89 & 1.70 & 1.27 & $6 / 10$ \\
\hline & $P I$ & 0.75 & 2.50 & 1.11 & 2.32 & 1.39 & 0.41 & 1.27 & 2.72 & 2.06 & $1.72^{*}$ & $8 / 10$ \\
\hline & $U I$ & 0.67 & 2.75 & 0.74 & 1.26 & 1.33 & 0.55 & 0.68 & 1.64 & 1.53 & 2.11 & $6 / 10$ \\
\hline & EI & 0.51 & 6.89 & 0.82 & 2.92 & 1.85 & 0.23 & 0.87 & 4.45 & 3.16 & 3.63 & $6 / 10$ \\
\hline \multirow{4}{*}{$\begin{array}{c}\mathrm{n} \\
>1\end{array}$} & $\overline{S I}$ & $6 / 7$ & $6 / 8$ & $4 / 8$ & $7 / 9$ & $4 / 9$ & $5 / 9$ & $3 / 9$ & $9 / 9$ & $7 / 9$ & $8 / 9$ & \\
\hline & $P I$ & $3 / 7$ & $4 / 8$ & $5 / 8$ & $7 / 9$ & $6 / 9$ & $6 / 9$ & $3 / 9$ & $9 / 9$ & $8 / 9$ & $7 / 9$ & \\
\hline & $U I$ & $0 / 7$ & $3 / 8$ & $3 / 8$ & $6 / 9$ & $5 / 9$ & $2 / 9$ & $3 / 9$ & $8 / 9$ & $3 / 9$ & $7 / 9$ & \\
\hline & $E I$ & $0 / 7$ & $3 / 8$ & $4 / 8$ & $7 / 9$ & $5 / 9$ & $5 / 9$ & $3 / 9$ & $8 / 9$ & $6 / 9$ & $7 / 9$ & \\
\hline \multirow{4}{*}{$\overline{\mathrm{x}}$} & $S I$ & 1.27 & 1.10 & 0.91 & 1.39 & 0.99 & 1.05 & 0.91 & 2.11 & 1.51 & 1.21 & 7 \\
\hline & $P I$ & 0.88 & 1.47 & 2.13 & 1.55 & 3.59 & 6.05 & 23.71 & 4.66 & 1.85 & 1.54 & 9 \\
\hline & $U I$ & 0.61 & 0.98 & 0.97 & 0.97 & 1.39 & 1.24 & 0.97 & 2.10 & 0.98 & 1.41 & 4 \\
\hline & EI & 0.53 & 1.45 & 2.06 & 1.51 & 5.00 & 7.49 & 22.92 & 9.77 & 1.80 & 2.18 & 9 \\
\hline
\end{tabular}

Performans ve kullanım endeksleri birlikte ele alındığında; performans endeks değerlerine göre kalemler bazında çalışma sermayesi yönetiminde verimli olduğu ancak bütün olarak bakıldığında bütün olarak çalışma sermayesi yönetimi kullanımının işletme performansını destekleyecek yönde olmadığı söylenebilir. Diğer yandan çalışma sermayesi yönetimi etkinliğinin çalışma sermayesi yönetimi performans endeksindeki başarının sonucu olarak gerçekleştiği çalışma sermayesi kullanımının çalışma sermayesi yönetim etkinliğini zayıflattığı söylenebilir. İşletmeler bazında incelendiğinde bu duruma en iyi örnek MAALT işletmesinin 
durumudur. Tüm endeks değerlerine göre en başarılı işletme AYCES'tir. İşletmenin 10 yıllık dönemde performans, kullanım ve etkinlik endekslerinin 1'den yüksek olduğu yıl sayıları (n) sırasıyla 8, 6 ve 7'dir. İşletmenin çalışma sermayesi yönetimi performans endeksinin belirli bir aralıkta, kullanım endeksi genel olarak $1-2$ arasında değişmesi işletme etkinlik endeksinin 2010, 2011 ve 2016 yılları dışında 1'in üzerinde ve dengeli seyretmesi işletmenin çalışma sermayesi yönetiminde belirli bir politikaya sahip olduğuna işaret etmektedir. Elde edilen bulgulara göre satışların düştüğü dönemlerde çalışma sermayesi yönetim etkinliğinin zayıf olduğu belirtilebilir. Türkiye turizmi ve özellikle konaklama sektörü için 2016 yılının zorlu bir yıl olmasının yanında işletmelerde çalışma sermayesi kullanım ve yönetiminin işletmelerin aleyhinde sonuçlara sebep olduğu belirtilebilir. AYCES ve MARTI dişındaki diğer işletmelerde performans, kullanım ve etkinlik endeks değerleri incelendiğinde dalgalı bir seyir öne çıkmaktadır. Yıllar itibariyle endeks düzeylerine göre etkin işletme sayıları 2010 yılında tüm işletmelerde çalışma sermayesi yönetiminin etkin olmadığı, 2013 ve 2019 yıllarında 7 işletmenin, 2017 y1lında ise 8 işletme çalışma sermayesi yönetimi etkindir.

Havayolu işletmeleri çalışma sermayesi yönetimi etkinlik endeks bulgularının yer aldığı Tablo 4 incelendiğinde, performans ve kullanım endeksinin büyük dalgalanmalar göstermediği performans endeksinin 0.52 (PGSUS: 2013) ile 1,56 (THYAO: 2012) aralığında gözlenmiştir. 2014 ve 2015 yıllarında iki işletmenin de performans endeksinin 1'in altında olduğu 2017 yılında ise iki işletmenin de performans endeksinin 1'in üzerinde olduğu görülmektedir. 2010 - 2012 yıllarında THYAO'nun performans endeksi 1'in üzerinde olduğu görülmektedir. Havayolu işletmelerinde satış endekslerinin tüm yıllarda olumlu olması (SI $>1$ ) çalışma sermayesi kalemleri yönetiminde satışları arttırma, bununla birlikte atıl fon bulundurmaktan kaçınma yönlü olduğu söylenebilmektedir. Havayolu ulaştırma işletmelerinde 0.36 (PGSUS: 2013) ve 1.34 (PGSUS: 2016) aralığında değişen kullanım endeksi değerleri, bütün olarak çalışma sermayesinin satışların arttırılmasında katkı sağladığı ve düzenli seyir izlemesi çalışma sermayesi yönetiminde belirli bir düzeyin korunmaya çalışıldığını göstermektedir.

Tablo 4. Havayolu ulaştırma işletmeleri çalışma sermayesi yönetimi etkinliği

\begin{tabular}{|c|c|c|c|c|c|c|c|c|c|c|c|c|}
\hline İşletme & Endeks & 2010 & 2011 & 2012 & 2013 & 2014 & 2015 & 2016 & 2017 & 2018 & 2019 & $\begin{array}{c}\mathbf{n} \\
>\mathbf{1}\end{array}$ \\
\hline \multirow{4}{*}{ PGSUS } & $S I$ & - & - & - & 1.25 & 1.28 & 1.13 & 1.06 & 1.44 & 1.55 & 1.33 & $7 / 7$ \\
\hline & $P I$ & - & - & - & 0.52 & 0.85 & 0.80 & 1.15 & 1.00 & 0.98 & 1.15 & $3 / 7$ \\
\hline & $U I$ & - & - & - & 0.36 & 1.03 & 0.92 & 1.34 & 0.68 & 1.09 & 0.97 & $3 / 7$ \\
\hline & $E I$ & - & - & - & 0.19 & 0.87 & 0.74 & 1.53 & 0.68 & 1.07 & 1.11 & $3 / 7$ \\
\hline \multirow{4}{*}{ THYAO } & $S I$ & 1.20 & 1.40 & 1.25 & 1.27 & 1.29 & 1.19 & 1.02 & 1.35 & 1.58 & 1.20 & 10 \\
\hline & $P I$ & 1.08 & 1.06 & 1.56 & 1.13 & 0.87 & 0.89 & 0.76 & 1.30 & 1.02 & 0.97 & $6 / 10$ \\
\hline & $U I$ & 0.96 & 1.20 & 1.32 & 1.08 & 0.89 & 0.85 & 0.74 & 1.25 & 0.91 & 1.00 & $5 / 10$ \\
\hline & $E I$ & 1.04 & 1.27 & 2.05 & 1.22 & 0.78 & 0.76 & 0.56 & 1.62 & 0.93 & 0.97 & $5 / 10$ \\
\hline \multirow{4}{*}{$\begin{array}{c}\mathrm{n} \\
>1\end{array}$} & $S I$ & $1 / 1$ & $1 / 1$ & $1 / 1$ & $2 / 2$ & $2 / 2$ & $2 / 2$ & $2 / 2$ & $2 / 2$ & $2 / 2$ & $2 / 2$ & \\
\hline & $P I$ & $1 / 1$ & $1 / 1$ & $1 / 1$ & $1 / 2$ & 0 & 0 & $1 / 2$ & $2 / 2$ & $1 / 2$ & $1 / 2$ & \\
\hline & $U I$ & $0 / 1$ & $1 / 1$ & $1 / 1$ & $1 / 2$ & $1 / 2$ & 0 & $1 / 2$ & $1 / 2$ & $1 / 2$ & $1 / 2$ & \\
\hline & $E I$ & $1 / 1$ & $1 / 1$ & $1 / 1$ & $1 / 2$ & 0 & 0 & $1 / 2$ & $1 / 2$ & $1 / 2$ & $1 / 2$ & \\
\hline \multirow{4}{*}{$\overline{\mathrm{x}}$} & $S I$ & 1.20 & 1.40 & 1.25 & 1.26 & 1.29 & 1.16 & 1.04 & 1.40 & 1.57 & 1.27 & 10 \\
\hline & $P I$ & 1.08 & 1.06 & 1.56 & 0.83 & 0.86 & 0.85 & 0.96 & 1.15 & 1.00 & 1.06 & 6 \\
\hline & $U I$ & 0.96 & 1.20 & 1.32 & 0.72 & 0.96 & 0.89 & 1.04 & 0.97 & 1.00 & 0.99 & 4 \\
\hline & $E I$ & 1.04 & 1.27 & 2.05 & 0.71 & 0.83 & 0.75 & 1.05 & 1.15 & 1.00 & 1.04 & 8 \\
\hline
\end{tabular}

Havayolu ulaştırma işletmelerinde etkinlik endeks değerleri 0.19 (PGSUS: 2013) ile 2.05 (THYAO: 2012) aralığında değişmektedir. Ortalama açısından incelendiğinde çalışma sermayesi etkinliğinin 1 dolaylarında olması sektörün çalışma sermayesi yönetimini satışları 
destekler düzeyde hedef bir çalışma sermayesi düzeyine sahip olduğu belirtilebilir. 2014 ve 2015 yıllarında çalışma sermayesi yönetiminin her iki işletmede de etkin olmadığı, satışlar artarken çalışma sermayesinin daha fazla arttırıldığı bunun ise ilave maliyetlere neden olacağ için satışların daha fazla arttığ dönemlerde etkinliğin 1'den yüksek olması bu yıllarda çalışma sermayesi yönetimi etkinliğinin zayıf olduğuna işaret etmektedir.

\section{SONUÇ VE DEĞERLENDİRME}

Çalışma sermayesi yönetimiyle ilgili kararların işletme likiditesine, satışların artırılmasına, kapasite kullanımına, kârlılık ve firma değerine etkileri etkinliğin sağlanması önem taşımaktadır. Yönetici kararlarından etkilenen çalışma sermayesi etkinliği literatürde çeşitli yöntemlerle incelenmektedir. Çalışma sermayesi etkinliğinin incelenmesinde sıklıkla nakit dönüş süresi, net çalışma sermayesi, oran analizi gibi yöntemler kullanılmaktadır. Son yıllarda artan ilgiye rağmen henüz sınırlı sayıda çalışmada kullanılan Bhattacharya (1997)'nın geliştirdiği endeks yöntemi ise alternatif bir çalışma sermayesi etkinliği ölçüm ve değerlendirme yöntemidir.

Endeks yöntemi, işletmenin satışlarını artırmada çalışma sermayesi yatırım kararlarının etkinliğini ölçmektedir. Yöntem, dönen varlık unsurlarını ayrı ayrı ve bütün olarak hesaplamalara dahil ederek çalışma sermayesi yönetim etkinliğinin incelenmesine imkân vermektedir. Endeks yöntemiyle satışlarda daralmanın yaşandığı dönemlerde, çalışma sermayesi yatırım kararlarında yönetici tepkisinin belirlenmesini sağlamaktadır. Endeks yönteminde, performans, kullanım ve etkinlik endeks değerlerinin 1'den büyük olması, yönetimin varlık kullanım performanslarının sonucunda etkinliğin sağlandığını göstermektedir. Diğer ifadeyle çalışma sermayesi yönetiminde yöneticilerin başarılı olduğunun göstergesidir. Genel bir ifadeyle Bhattacharya (2007)'nın endeks yöntemi, satışlarla çalışma sermayesi unsurlarının değişimlerini dikkate alarak bu değişimlerin oransal büyüklüğüne göre yönetim kararlarının etkinliğinin ölçümü ve değerlendirilmesine olanak sağlamaktadır. Yöntemden elde edilen bulguların bu genel çıkarımının yanı sıra diğer çeşitli alt gösterge ve çıktıları söz konudur. Bunlardan ilk, yönetmeden elde edilen bulgular, satışlardaki değişimlerin çalışma sermayesi yatırım politikalarından etkilenip etkilenmediğine ilişkin kanıtlar sunmaktadır. Satışlardaki değişimlere karşı çalışma sermayesi yatırım kararlarına bağlı olarak dönen varlıklardaki değişimin yönü ve büyüklüğünü dikkate alan yöntem, ikinci olarak çalışma sermayesi ile satışlar arasındaki simetrik veya asimetrik ilişkilerin belirlenmesini mümkün kılmaktadır. Üçüncü olarak, endeks yöntemde hesaplanan performans endeksiyle dönen varlık unsurlarındaki değişimlerin ayrı ayrı hesaplanarak yönetimin dönen varlık unsurları bazında performansının incelenmesine olanak sağlamaktadır.

Yöntemde dönen varlık unsurlarının tutarlarından kaynaklanan oransal değişimler bozucu etkileri performans endeksinin tek başına yorumlanmasının önüne geçmektedir. Ancak yöntem bu bozucu etkinin giderilmesinde dönen varlıkların bütününü dahil eden kullanım endeksini etkinlik endeksine dahil etmektedir. Bu ise kullanım endeksiyle satışların gerçekleştirilmesinde dönen varlıkların kullanım etkinliğinin ölçümünü sağlamaktadır. Bu bilgilerle birlikte endeks yöntemiyle, farklı büyüklüklerdeki işletmelerin kıyaslanabilmesi avantajlı yönlerindendir. Bunun yanı sıra yöntemin tutar yerine oran ve ilişkilere dayalı olması yöntemin üstün yönlerindendir. Endeks yönteminde, performans ve kullanım endekslerinin birlikte ele alınmasıyla işletmede çalışma sermayesi yönetim etkinliğinin ölçülmesi, etkinliğin ise sabit bir değer olan " 1 " ile ölçülerek etkinliğin derecesi hakkında bilgi sunması yöntemin üstün yönlerinden biridir. Sayılan üstünlüklerinin yanında endeks yönteminde çalışma sermayesi 1426 
finansman kararlarının dikkate alınmaması yöntemin en temel zayıf yönlerinden biridir. Nihai olarak bakıldığında, Bhattacharya (2007) endeks yöntemini işletmelerde maliyet, fon, sermaye yönetimi gibi konularda da kullanılabilirliğini ortaya koyarken yöntemle hesaplanan endeks değerlerinin finansla ilgili diğer konularda da modellere kolay bir şekilde dahil edilebilir olması yöntemi öne çıkarmaktadır.

Bu kapsamda bu çalışmada endeks yöntemi açıklanmış ve yiyecek içecek, konaklama ve havayolu ulaştırma işletmelerinde çalışma sermayesi etkinliği incelenmiştir. Payları Borsa İstanbul'da işlem gören 11 işletmenin 2010-2019 dönemi yıllık gözlemlerinde endeks değerleri hesaplanmıştır. Elde edilen bulguların sektörün özellikleri ve sektörü etkileyen gelişmeler çerçevesinde irdelenmesi sonuçların anlamlı şekilde yorumlanmasını sağlayacaktır. Bu doğrultuda Türkiye'nin son yıllarda karşı karşıya kaldığı terör eylemleri, Rusya ile yaşanan uçak krizi, Fethullahçı terör örgütünün darbe kalkışması bu olayların sadece bir kaçıdır. Dolayısıyla özellikle bu ve benzeri gelişmeler Türk turizm sektörünü doğrudan veya dolaylı olarak etkilemektedir. Ayrıca, Türkiye'nin turizm pazarlarında yaşanan gelişmeler Türk turizm sektörüne ve işletmelerin faaliyetlerine etkileri olmaktadır. Yöneticilerin gelişmeler karşısında aldıkları kararlar işletmelerin krizlerden etkilenme düzeylerini belirlemektedir.

Çalışmada yiyecek-içecek ve konaklama sektör işletmelerinin havayolu sektörü işletmelerine kıyasla çalışma sermayesi yönetiminde etkinliklerinin daha zayıf olduğu sonucuna ulaşılmıştır. Yiyecek içecek ve konaklama işletmeleri endeks değerlerinin dalgalı seyri, bu işletmelerin çalışma sermayesi yönetiminde belirli bir yatırım politikasına sahip olmadıklarını göstermektedir. Borsa İstanbul lokantalar ve oteller sektör sınıfında yer alan yiyecek içecek ve konaklama işletmeleri performans endekslerinde gözlemlenen dalgalı seyir Kandil Göker (2018)'in gida sektörü işletmelerinde elde ettiği bulgularla kısmi olarak benzerlik göstermektedir. Yiyecek içecek ve konaklama işletmeleri performans, kullanım ve etkinlik endekslerinin havayolu ulaştırma işletmelerine göre daha dengesizdir. Bu bulgular havayolu ulaştırma işletmelerinin literatürdeki çalışmalarla (Marie ve Azhagaiah, 2017b; Güler ve Konuk, 2019) benzer etkinlik düzeyine sahip olduğunu göstermektedir, Kasiran, Mohamad ve Chin (2016)'in Malezya KOBİ örneğinde yaptıkları çalışmada etkinlik endeksi genellikle 0'a yakınken, bu çalışmada yiyecek içecek, konaklama ve havayolu ulaştırma işletmelerinin başarılı olduğu belirtilebilir. Havayolu ulaştırma işletmelerinde çalışma sermayesi yönetiminde belirli bir politikanın varlığından söz edilebileceği gibi etkinliğin sağlanmasında ve satışların artırılmasında mevcut politikanın olumlu etkileri gözlenmektedir.

Yiyecek içecek ve konaklama sektörlerinde faaliyet gösteren işletmelerin çalışma sermayesi yatırım kararlarında diğer ifadeyle dönen varlık yönetiminde, varlık kaynak vade uyumunun göz ardı edildiği ve atıl fonlara sebep olan nakit ve benzeri varlıklar ile finansal varlık bulundurmaları, alacak ve stok düzeylerini optimal düzeyde belirlemeleri satışlardaki değişime duyarlı kararlar almaları işletmelerin lehine sonuçlar ortaya koyacaktır. İşletmelerin faaliyet ve finansal risklere karşı yatırım ve finansman kararlarında etkin yönetim anlayışını benimsemesi işletmelerin başarısız olmasının önüne geçecektir. Dolayısıyla çalışma sermayesi yatırım kararlarında etkinliğin sağlanması ile işletmenin bütüncül performansı olumlu etkileneceği gibi satışlardaki değişimlere karşı finansman maliyetlerini karşılayamayacak şekilde dönen varlık kalemlerine yatırım yapılması işletmenin zarar etmesine, mali yapısını bozarak kredibilitesini zayıflatacağı unutulmamalıdır. İşletmelerde dönen varlık kalemlerinin gerek ayrı ayrı gerek bütün olarak incelenerek işletmelerin çalışma sermayesi yatırım politikalarına yön vermesi etkinliğin sağlanmasına katkı sağlayacaktır. 
Endeks yöntemiyle yapılan çalışmaların literatürde sınırlı olması, yöntemin kısıtlarından öte henüz yeterince bilinmediğinden kaynaklandığı düşünülmektedir. $\mathrm{Bu}$ nedenle endeks yönteminin diğer sektörlerde, farklı dönem ve farklı finansal rapor dönemlerinde uygulanması literatürdeki eksikliğin giderilmesine katkı sağlayacağı düşünülmektedir. Endeks yönteminin diğer yöntemlerle karşılaştırılması, endeks değerlerinin kolaylıkla modellenebilir ve karşılaştırılabilir olması nedeniyle çalışma sermayesi yönetimi etkinliğinin işletme performansına etkilerinin incelendiği çalışmalarda endeks yönteminin kullanımı önerilmektedir.

\section{KAYNAKÇA}

AFZA, T. \& NAZİR, M. S. (2011). "Working Capital Management Efficiency of Cement Sector of Pakistan". Journal of Economics and Behavioral Studies, 2(5): 223-235.

AKBULUT, R. (2011). “İMKB'de İmalat Sektöründeki İşletmelerde İşletme Sermayesi Yönetiminin Karlılık Üzerindeki Etkisini Ölçmeye Yönelik Bir Araştırma”. İstanbul Üniversitesi İşletme Fakültesi Dergisi, 40(2): 195-206.

AKSOY, A. \& YALÇINER, K. (2008). İşletme Sermayesi Yönetimi, (4. Baskı), Gazi Kitabevi, Ankara.

ALİ, S. (2011). "Working Capital Management and the Profitability of the Manufacturing Sector: A Case Study of Pakistan's Textile Industry", The Lahore Journal of Economics, 16(2): 141-178.

ALTMAN, E. I. (1968). "Financial Ratios, Discriminant Analysis and the Prediction of Corporate Bankruptcy”, The Journal of Finance, 23(4): 589-609.

APPUHAMI, B. R. (2008). “The Impact of Firms' Capital Expenditure on Working Capital Management: An Empirical Study across Industries in Thailand”, International Management Review, 4(1): 8-21.

ASHRAF, C. K. (2012). "The Relationship between Working Capital Efficiency and Profitability", Journal of Accounting and Management, 2(3): 21-45.

ATA, H. A. \& BUĞAN, M. F. (2016). "İmalat Şirketlerinde Çalışma Sermayesi Etkinliğinin Firma Değerine Etkisi Nasıldır?”, Selçuk Üniversitesi Sosyal Bilimler Enstitüsü Dergisi, 35: 25-33.

AYDIN, N., BAŞAR, M. \& COŞKUN, M. (2018). Finansal Yönetim, (5. Baskı), Detay Yayıncilık, Ankara.

BAÑOS-CABALLERO, S., GARCÍA-TERUEL, P. J. \& MARTÍNEZ-SOLANO, P. (2010). "Working Capital Management in SMEs", Accounting \& Finance, 50(3): 511-527.

BARINE, M. N. (2012). “Working Cpital Management Efficiency and Corporate Profitability: Evidences from Quoted Firms in Nigeria", Journal of Applied Finance and Banking, 2(2): $215-237$.

BEAVER, W. H. (1966). "Financial Ratios As Predictors of Failure", Journal of Accounting Research, 4: 71-111. 
BEYAZGÜL, M. \& KARADENIZ, E. (2020). "Konaklama İşletmelerinde Çalışma Sermayesinin Kârlılığa Etkisinin Analizi: Türkiye-Amerika Birleşik Devletleri Karşılaştırması", Journal of Tourism and Gastronomy Studies, 8(3): 2029-2049.

BHATTACHARYA, H. (1997). Total Management by Ratios. Sage publications, New Delhi.

BHATTACHARYA, H. (2007). Total Management by Ratios: An Analytic Approach to Management Control and Stock Market Valuations. (2. Edt.), Sage publications, New Delhi.

BIENIASZ, A. \& GOŁAŚ, Z. (2011). “The Influence of Working Capital Management on the Food Industry Enterprises Profitability”, Contemporary Economics, 5(4): 68-81.

BRIDGE, J. \& MOUTINHO, L. (2000). "Financial Management in Tourism", L. Moutinho (Editör), Strategic Management in Tourism, (187-210), CABI Publishing, London.

BRIGHAM, E. F. \& HOUSTON, J. F. (2009). Fundamentals of Financial Management, (12. Bask1), South-Western Cengage Learning, ABD.

CEYLAN, A. \& KORKMAZ, T. (2018). İşletmelerde Finansal Yönetim, (16. Baskı). Ekin Basım Yayın Dağıtım, Bursa.

DELOOF, M., (2003). "Does Working Capital Management Affect Profitability of Belgian Firms?", Journal of Business, Finance and Accounting, 30: 573-587.

ENQVIST, J., GRAHAM, M., \& NIKKINEN, J. (2014). “The Impact of Working Capital Management on Firm Profitability in Different Business Cycles: Evidence from Finland". Research in International Business and Finance, 32: 36-49.

ERDINÇ, S. B. (2008). "Konaklama İşletmelerinde İşletme Sermayesi Yönetiminin İncelenmesi”, Afyon Kocatepe Üniversitesi İktisadi ve İdari Bilimler Fakültesi Dergisi, 10(2), 223-236.

EREM CEYLAN, I. (2020). "Measuring Efficiency of Working Capital Management: Index Method", Journal of Economics Business and Organization Research, The Third Economics, Business and Organization Research (EBOR) Conference, Special Issue: 238-246.

FIADOR, V. (2016). "Does Corporate Governance Influence the Efficiency of Working Capital Management of Listed Firms: Evidence from Ghana", African Journal of Economic and Management Studies, 7(4): 482-496.

GARCÍA-TERUEL, P. J. \& MARTÍNEZ-SOLANO, P. (2007). "Effects of Working Capital Management on SME Profitability”, International Journal of Managerial Finance, 3(2): 164-177.

GENTRY, J. A., NEWBOLD, P. \& WHITFORD, D. T. (1984). "Bankruptcy, Working Capital and Funds Flow Components", Managerial Finance, 4: 71-111.

GHOSH, D. S. K., \& MAJI, S. G. (2004). "Working Capital Management Efficiency: A Study on the Indian Cement Industry", Management Accountant-Calcutta-, 39: 363-372. 
GILL, A. S. \& BIGER, N. (2013). "The Impact of Corporate Governance on Working Capital Management Efficiency of American Manufacturing Firms", Managerial Finance. 39(2): 116-132.

GÜLER, E. \& KONUK, F. (2019). “Çalışma Sermayesi Etkinlik Ölçümünde Alternatif Bir Araç: İndeks Yöntemi”, Muhasebe ve Finansman Dergisi, 84: 35-48.

GÜNAY, F. \& BÖYÜKASLAN, A. (2020). “Otel İşletmelerinde Fizibilite Çalışmaları”, T. Pala ve M. Tepeci (Editörler), Otel İşletmelerinin Yönetimi, Operasyonel Süreç ve Yönetim Uygulamaları, (249-274), Detay Yayıncılık, Ankara.

HELHEL, Y. \& KARASAKAL, S. (2017). "Konaklama İşletmelerinde Çalışma Sermayesi Yönetiminin Karlılık Performansına Etkisi: Borsa İstanbul'da (BİST) Bir Uygulama”, Seyahat ve Otel İşletmeciliği Dergisi, 14(3): 27-39.

HIADLOVSKÝ, V., RYBOVIČOVÁ, I. \& VINCZEOVÁ, M. (2016). "Importance of Liquidity Analysis in the Process of Financial Management of Companies Operating in the Tourism Sector in Slovakia: An Empirical Study", International Journal for Quality Research, 10(4): 799-812.

KAMAU, S. M. \& BASWETI, K. A. (2013). "The Relationship between Corporate Governance and Working Capital Management Efficiency of Firms Listed at the Nairobi Securities Exchange", Research Journal of Finance and Accounting, 4(19): 190-199.

KANDİL GÖKER, İ. E. (2018). "Çalışma Sermayesi Yönetiminde Etkinlik Durumunun Tespiti: BIST Gıda Sektörü Firmaları Üzerine Bir Araştırma”, Uluslararası Yönetim Eğitim ve Ekonomik Perspektifler Dergisi, 6(3): 69-79.

KANDİL GÖKER, İ. E. (2020). “An Analysis of Working Capital Efficiency of Companies Listed on Sustainability Index by Index Method", Journal of Economics Finance and Accounting, 7(2): 94-102.

KARAGÖZOĞLU, G., AKTAŞ, R. \& KAYALIDERE, K. (2019). "Çalışma Sermayesi İle Faaliyet Performansı Göstergesi Olan Etkinlik Arasındaki İlişkinin Tespiti”, Muhasebe ve Finansman Dergisi, (83): 231-248.

KARAKAYA, A., KURTARAN, A. \& DAĞLI, H. (2014). "Bireysel Emeklilik Şirketlerinin Veri Zarflama Analizi ile Etkinlik Ölçümü: Türkiye Örneği”, Yönetim ve Ekonomi Araştırmaları Dergisi, 12(22): 1-23.

KASIRAN, F. W., MOHAMAD, N. A. \& CHIN, O. (2016). "Working Capital Management Efficiency: A Study on the Small Medium Enterprise in Malaysia", Procedia Economics and Finance, 35: 297-303.

KAUR, H. V. \& SINGH, S. (2013). "Managing Working Capital Efficiency in Capital Goods Sector in India", Global Business Review, 14(2): 343-355.

KAVITHA, R. \& SHANMUGAM, R. (2015). A Study on Working Capital Management Efficiency" International Journal of Engineering and Management Research (IJEMR), 5(3): 196-208. 
KENDİRLİ, S. \& ÇANKAYA, M. (2016). "BİST Turizm Endeksindeki Şirketlerde İşletme Sermayesi Yönetiminin Karlılık Üzerindeki Etkisini Ölçmeye Yönelik Bir Araştırma”, International Review of Economics and Management, 4(2): 46-68.

KORKMAZ, T. \& YAMAN, S. (2019). “Impact of Working Capital Management on Firm's Profitability: An Application on BIST Tourism Companies", Journal of Tourism Theory and Research, 5(2): 301-316.

MARIE, A. A. \& AZHAGAIAH, R. (2017a). "Constructing Indices for Efficient Management of Working Capital in Indian Iron and Steel Sector", Anvesha, 10(3): 21-32.

MARIE, A. A. \& AZHAGAIAH, R. (2017b). "Determining Index of Working Capital Management for Indian FMCG Sector (Empirical Evidence on Its Contribution to Efficiency)", International Journal of Research in Business Studies, 2(2): 101-112.

MOYER, R. C., MCGUiGAN, J. R. \& KRETLOW, W. J. (2006). Contemporary Financial Management, (10. Bask1). South-Western, ABD.

OKKA, O. (2009). Analitik Finansal Yönetim, Nobel Yayın Dağıtım, Ankara.

RAHEMAN, A. VE NASR, M. (2007). "Working Capital Management and Profitability-Case of Pakistani Firms", International Review of Business Research Papers, 3(1): 279-300.

RAMACHANDRAN, A. VE JANAKIRAMAN, M. (2009). "The Relationship between Working Capital Management Efficiency and EBIT”, Managing Global Transitions: International Research Journal, 7(1): 61-74.

SALDANLI, A. (2012). "Likidite ve Karlılık Arasındaki İlişki-İMKB 100 İmalat Sektörü Üzerine Ampirik Bir Çalışma”, Süleyman Demirel Üniversitesi Sosyal Bilimler Enstitüsü Dergisi, 16: 167-176.

SHAW, G., SAAYMAN, M. VE SAAYMAN, A. (2012). "Identifying Risks Facing the South African Tourism Industry", South African Journal of Economic and Management Sciences, 15(2), 190-206.

ŞEN. M. \& ORUÇ. E. (2009). "Relationship between Efficiency Level of Working Capital Management and Return on Total Assets in ISE", International Journal of Business and Management, 4(110): 109-114.

VALIPOUR, H. \& JAMSHIDI, A. (2012). "Determining the Optimal Efficiency Index of Working Capital Management and Its Relationship with Efficiency of Assets in Categorized Industries: Evidence from Tehran Stock Exchange (TSE)", Advances in Management and Applied Economics, 2(2): 191-209.

YAVUZ, İ. (2003). Verimlilik ve Etkinlik Ölçümüne Yeni Yaklaşımlar ve İllere Göre İmalat Sanayinde Etkinlik Karşılaştırmaları, Ankara, MPM Yayınları, No: 667. 